\title{
“Kırk yedi yıl sonra yeniden bir salgının hikayesi: 1970 Sağmalcılar kolera salgınından günümüze dersler"e yanıt
}

\author{
Necati Dedeoğlu a \\ a Prof. Dr., Başkent Üniversitesi, Tıp Fakültesi Halk Sağlığı AD, Ankara
}

Geliş tarihi: 03.01.2018, Kabul tarihi: 28.01.2018

Sayın Editör,

2017; 15 (3) sayılı derginizde Dr. Coşkun Bakar tarafından yazılmış bulunan "Kırk yedi yıl sonra yeniden bir salginın hikayesi: 1970 Sağmalcılar kolera salgınından günümüze dersler" isimli makalesi ilginç bir hikayeyi dile getirmekte ve önemli dersler aktarmaktadır.

Ben salgını, makalede de ismi "Merkez Hifzıssıhha Okulu Epidemiyoloji Uzmanı" olarak geçen rahmetli Hocam Muzaffer Akyol'dan dinledim. Kendisi salgının incelemesinde bulunmuștu. Onun anlattığına göre:

Sağmalcılar Doğudan göç alan bir gecekondu semtidir. Gecekondusunu inşa eden göçmenin ikinci yapacağı şey tuvalet çukuru açmaktır. Bölgede tuvalet yapanlar bir-iki metre kazdıktan sonra bir boşluğa rastlamışlar, kulübeyi bu boşluk üstüne oturtmuşlar. Aynı şekilde su temini için kuyu kazanlar da birkaç metre sonra dibinde su olan bir boşluğa rastlamışlar. Aslında her iki boşluk da Bizanslıların yer altı sularını toplamak için inşa ettikleri galerilerdir. Bizanslılar İstanbul'un suyunun bir kısmını yerüstünden, su kemerleri ile taşınmaktaydı. Ancak bir kuşatma sırasında bu su kolayca engellenip kent susuz birakılabilirdi. Oysa yeraltından birbirine bağlı galeriler tarafindan toplanan su "Yerebatan Sarayı", "Binbirdirek" gibi büyük sarnıçlarda toplanarak kentin su ihtiyacını uzun süre karşılayabilirdi. Kısacası Sağmalcılarda hem tuvaletler, hem su kuyuları aynı yer altı su kanallarına açllıyordu. Kuşkusuz açıktan akan lağımlar, kontamine mahalle çeşmeleri gibi faktörlerin de koleranın hızla yayılmasında rolü vardır.

Aslında 1961 yılında Endonezya'da başlayan salgının batıya doğru ilerlediği biliniyordu (Makalede Şekil 1). 1969 da Tebriz'de ve Suriye'de hududa yakın yerlerde salgınlar görülmüştü. Makalede de

Sorumlu Yazar: Necati Dedeoğlu, Başkent Üniversitesi, Tıp Fakültesi, Halk Sağlığı AD, Ankara; E-posta: necodedeoglu@gmail.com 
belirtildiği gibi Prof. Dr. Behiç Onul gibi hekimler hükümeti kolera konusunda uyarmışlardı. Ancak büyük şehirlerin hızla büyümüş olan gecekondu semtlerinin hepsinde su ve kanalizasyon sorunu vard. Aslında kent merkezlerinin de altyapısı bozuktu. Koleranın Sağmalcılardan İstanbul'un başka semtlerine ve hatta başka kentlere kolayca yayllabilmesinin nedeni budur. Yani uyarıldıysa bile bu altyapı koşullarında Bakanlığın yapabileceği fazla bir şey yoktu.

Salgın etkeninin geç tanımlanması, hatta meşhur hekimlerce de "Bu \%100 kolera değil" denmesinin nedeni etkenin, klasik koleradan farklı bir klinik tablo ile seyreden El-Tor biotipi olmasıdır. 1930'larda Misır'ın El-tor kasabasında keşfedilen ve patojen olmayan suş daha sonra virulans kazanıp Endonezya'nın Celebes adalarından dünyaya yayılarak 7 . kolera pandemisini başlatmıștır. Bu pandemi azalarak da olsa, günümüzde devam etmektedir. ${ }^{1}$ El-tor tipi klasik koleradan daha hafif bir klinik tablo gösterir. Pek çok gizli veya hafif bir enteritle seyreden vakalar bulunur. Bu durum, ülkemizde de yaşandığı gibi hem hastalığın tanısının konmasını geciktirir hem de kolayca yayılmasını sağlar.

Komşularımızın ve Avrupa
ülkelerinin ülkemizdeki koleraya karşı
tutumları da ilginçtir. Sınırlar kapatılmış,
gemi, tren seyahatleri durdurulmuş, turizm
önemli oranda aksamıştır. Bu önlemlerin bir
kısmı o zaman ilişkilerimizin pek de iyi
olmadığı komşu ülkelerin salgını fırsat bilen
olumsuz yaklaşımlarından
kaynaklanmaktadır. Diğer bir kısmı ise El-tor
kolerasının epidemiyolojisinin henüz
bilinmemesine bağlıdır. Koleranın o çok
korkulan öldürücü kolera tipi olmadığı ve sık
olarak sağlam görünüşlü insanlardan
bulaşabileceği bilinmiyordu. Ayrıca alt yapısı
sağlam olan ülkelerin koleradan veya diğer
sindirim sistemi hastalıkları salgınlarından
korkmaması gerekirdi. Nitekim pandemi
ülkemizden sonra Avrupa'ya değil, Afrika'ya
geçmiştir. Çekoslavakya veya birkaç ülkede
bazı salgınlar olduysa da bunlar
yayılamamıştır. Zaten bir salgın riski olsaydı,
İngiltere gibi Avrupa ülkelerine bu

hastalıkların endemik oldukları Bangladeş, Hindistan gibi ülkelerden gelenler çok daha önce salgınlara neden olurdu. 1966 yılında salgın kuzeye, Sovyetler Birliğine sıçradı. Alma-Ata'da görülen salgının yayılmasını önlemek için kent ordu tarafindan kuşatılarak karantinaya alındıysa da birkaç hafta sonra karantinada görevli bir askerin izinli geldiği Odessa'da salgın patladı. Yazarın da belirttiği gibi kolerada karantina, ölülerin kireçlenip gömülmesi, evlere sarı kağıt yapıştırılması gibi önlemler yarasız hatta zararlıdır. Salgın kontrolü için etkisi kuşkulu aşılamaya ağırlık verilmesi de doğru olmamıștır. Buna karşın fekal-oral bulaşın engellenmesi, surveyans çalıșmaları ve halkın bilgilendirilmesi gibi önemli görevlere daha az önem verilmiştir.

1970 yılında Sağmalcılarla ülkemize giren kolera çevre koşulları nedeniyle endemik hale gelmiștir. Sonraki yıllarda pek çok kentimizde, küçük büyük birçok kolera salgınları olmuştur. Ancak komşu ülkelerin ve Avrupa ülkelerinin başka ülkelere uygulamadıkları sıkıntı yaratıcı kolera önlemlerini ülkemiz için uygulamaları nedeniyle olsa gerek, daha sonraki yıllarda Türkiye'den kolera ihbarı yapılmamıştır. Oysa dizanteri, tifo gibi hastalıkların bolca görüldüğü bir ülkede koleranın da bulunacağını bilmek için kahin olmaya gerek yoktur. Su ve kanalizasyon sistemlerini birbirinden ayırmayl henüz tam başaramamış, kentleri sel basmasını önleyememiş olan ülkemizde yeni kolera salgınlarının çıkması şaşırtıcı olmaz.

Dikkat çeken diğer bir konu, her zamanki gibi, salgının kamuoyundan saklama girişimleridir. Yazarın da belirttiği gibi hele günümüz Türkiye'sinde toplumsal olayları gizlemek hiç mümkün değildir. Üstelik bu davranış vatandaşın paniğe kapılmasına ve doğru bilgilere zamanında ulaşmasını da engellemektedir. Bu olumsuz yaklaşımın günümüze dek süregelmesi üzücüdür. Aynı şekilde, sorumluluk üstlenmekten kaçınan politikacıların felaketleri ilahi güçlere, fitratlara dayandırma alışkanlığı da ne yazık ki devam etmektedir. 
Sayın Dr. Coşkun Bakar'a gerçekten önemli dersler içeren bir sağlık olayını titiz bir inceleme ile tekrar gündeme getirdiği için teşekkür ederim.

\section{Kaynaklar}

1. Cholera Outbreaks and Pandemics. Erişim: $23 \quad$ Aralı 2017 https://ipfs.io/ipfs/QmXoypizjW3WknFiJn KLwHCnL72vedxjQkDDP1mXWo6uco/wiki

/Cholera_outbreaks_and_pandemics.html 